\title{
"Madness is Somewhere Else": A Marcusian Reading of Rainer Maria Rilke's Sonnets to Orpheus
}

\author{
"Delilik Başka Yerde": \\ Rainer Maria Rilke’nin Orpheus Sonelerinin Marcuse Perspektifinden Okumast
}

\begin{abstract}
Nina CEMILOĞLU *
Abstract: The aim of this article is to read Rainer Maria Rilke's Sonnets to Orpheus (Sonette an Orpheus) from a Marcusian perspective. This article is divided into five parts: The first part focuses on the representation of Orpheus in Rilke's sonnet cycle and on Marcuse's interpretation of the myths of Prometheus, Orpheus and Narcissus. The second part draws attention to the notion of a new sensibility characterized by receptivity and nonviolence in Sonnets to Orpheus and Marcuse's works. The third part explores Rilke's and Marcuse's views on narcissism. The fourth part points out affinities between Rilke's sonnet cycle and Marcuse's works with ecocritical ideas. The fifth part discusses the two writers' ideas on the function of poetry in society. A final paragraph sums up the conclusions drawn in the previous five parts of this article.
\end{abstract}

Keywords: Rainer Maria Rilke, Herbert Marcuse, German $20^{\text {th }}$-Century Poetry, Orpheus

Öz: Bu makalenin amac1, Rainer Maria Rilke'nin Orpheus'a Soneler (Sonette an Orpheus) eserini Marcuse'nin bakış açısıyla değerlendirmektir. Bu makale beş bölüme ayrılmıştır: İlk bölüm, Rilke'nin sone döngüsünde Orpheus'un temsiline ve Marcuse'nin Prometheus, Orpheus ve Narcissus mitleri hakkındaki yorumuna odaklanmaktadır. İkinci bölüm, Orpheus'a Soneler ve Marcuse'nin çalışmalarında alıcılık ve saldırmazlık ile karakterize edilen yeni bir duyarlılık kavramına dikkat çekiyor. Üçüncü bölüm Rilke’yi ve Marcuse'nin narsisizm hakkındaki görüşlerini incelemektedir. Dördüncü bölüm, Rilke'nin sone döngüsü ile Marcuse'nin ekoeleştirel fikirler üzerine çalışmaları arasındaki ilişkilere dikkat çekiyor. Beşinci kısım, iki yazarın, toplumda şiirin işlevi hakkındaki fikirlerini incelemektedir. Final paragrafı makalenin önceki beş bölümden çıkarılan sonuçları özetler.

Anahtar sözcükler: Rainer Maria Rilke, Herbert Marcuse, Alman 20. Yüzyıl Şiiri, Orpheus

\section{Prometheus, Orpheus, Narcissus}

The first sonnet of the first part of Rilke's Sonnets to Orpheus opens with a startling image - a tree in the ear: "A tree ascended there. Oh pure transcendence!/ Oh Orpheus sings! Oh tall tree in the ear!" ("Da stieg ein Baum. O reine Übersteigung!/ O Orpheus singt! O hoher Baum im Ohr!" Rilke 1982, 226- 227). The second sonnet of the first part opens with a similarly startling image a girl who makes her bed in the speaker's ear and sleeps there: "And it was almost a girl who, stepping from/ this single harmony of song and lyre,/ [...]/ made herself a bed inside my ear." ("Und fast ein Mädchen wars und ging hervor/ aus diesem einigen Glück von Sang und Leier/

\footnotetext{
* Dr. Öğr. Ü., Yeditepe Üniversitesi, Fen-Edebiyat Fakültesi, İngiliz Dili ve Edebiyatı Bölümü, İstanbul. nina.cemiloglu@yeditepe.edu.tr, https://orcid.org/0000-0002-3977-7314
} 
[...]/und machte sich ein Bett in meinem Ohr” Rilke 1982, 228-229). These two images - of a tree and a sleeping girl in the speaker's ear - evoke a host of associations: natural growth, hearing, listening, silence, dreams, the female principle, beauty and calm. In fact, the phrase "almost a girl" calls into question categories such as male and female. It can be argued that the first two sonnets of Rilke's sonnet cycle foreground values that have traditionally been accorded less value than their counterparts: Western societies have traditionally valued culture over nature, seeing over hearing, consciousness over unconsciousness and maleness over femaleness. The lines quoted above from the first two sonnets in Rilke's Sonnets to Orpheus can be interpreted as announcing a crucial purpose of the entire sonnet cycle: a re-evaluation of values.

Herbert Marcuse has also called for a re-evaluation of values. He has argued that the dominant values of the Western world are embodied by the ancient Greek mythological figure of Prometheus. Marcuse $(1998,161)$ has called Prometheus "the culture-hero of toil, productivity, and progress through repression". In Civilization and Its Discontents, Freud has claimed that civilization is based on repression. Marcuse has contested Freud's claim and suggested that in an advanced scientific and technological society (such as late capitalist society) it would be possible to create a non-repressive civilization. He has argued that this possibility is embodied by the ancient Greek mythological figures of Orpheus and Narcissus, who, unlike Prometheus, have not become culture heroes of the Western world and who embody pleasure, gratification of desire and fulfillment. Marcuse has claimed that Prometheus can be regarded as a symbol of the reality principle; Orpheus and Narcissus can be regarded as symbols of the pleasure principle. He has pointed out that the reality principle is linked to the realm of reason and consciousness; the pleasure principle is linked to the realm of the imagination, the subconscious and art. Marcuse has suggested that Orpheus can be considered as an archetype of the poet, liberator and peace-bringer; Narcissus as a symbol of beauty, calm and harmony among all living creatures:

[T]heirs is the image of joy and fulfillment; the voice which does not command but sings; the gesture which offers and receives; the deed which is peace and ends the labor of conquest; the liberation from time which unites man with god, man with nature (Marcuse 1998, 162).

In I, 3 in Sonnets to Orpheus, the song of Orpheus is referred to as "not desire,/ not wooing any grace that can be achieved; song is Being" ("Gesang, wie du ihn lehrst, ist nicht Begehr,/ nicht Werbung um ein unendlich noch Erreichtes;/ Gesang ist Dasein.” Rilke 1982, 230 my translation). True being requires transformation, as the following line from II, 12 indicates: "What shuts itself in abiding is already numb" " Was sich ins Bleiben verschließt, schon ists das Erstarrte" Rilke 1964, 78-79). In II, 12, it is further suggested that we must "pour out" ourselves "as a spring" in order to experience being: "He who pours himself out as a spring is recognized by recognition,/ that leads him enraptured through cheerful creation" "Wer sich als Quelle ergießt, den erkennt die Erkennung;/ und sie führt ihn entzückt durch das heiter Geschaffne" Rilke 1964, 78 my translation). These can be interpreted as implying that a transformed attitude toward life affords a recognition of the beauty and joyfulness of all living things.

Both Orpheus and Narcissus experience transformation - Narcissus is transformed into a flower; Orpheus is transformed into an invisible force which suffuses the entire natural world. Both Orpheus and Narcissus are able to transform their surroundings. Marcuse has argued that although Orpheus and Narcissus embody values that belong to the realm of phantasy, they are nonetheless related to reality - potential reality:

Trees and animals respond to Orpheus' language; the spring and the forest respond to Narcissus' desire. The Orphic and Narcissistic Eros 
awakens and liberates potentialities that are real in things animate and inanimate, in organic and inorganic nature - real but in the un-erotic reality suppressed (Marcuse 1998, 165).

The concept of "potential reality" presupposes the possibility of transformation. As pointed out above, transformation is a central theme in Rilke's sonnet cycle. For examle, in I, 1, Orpheus is depicted as transforming his surroundings:

O Orpheus sings! Oh tall tree in the ear!

And all things hushed. Yet even in that silence

A new beginning appeared (Rilke 1982, 227).

O Orpheus singt! O hoher Baum im Ohr!

Und alles schwieg. Doch selbst in der Verschweigung

ging neuer Anfang, Wink und Wandlung vor (Rilke 1982, 226).

Orpheus's music attracts the animals of the forest and soothes them. It is important to note that the animals do not become quiet because they are scared or wait for an opportunity to attack Orpheus or one another, but because they have become completely caught up in the act of hearing:

Creatures of stillness crowded from the bright

unbound forest, out of their lairs and nests;

and it was not from any dullness, not

from fear, that they were so quiet in themselves,

but from simply listening. Bellow, roar, shriek

seemed small inside their hearts (Rilke 1982, 227).

Tiere aus Stille drangen aus dem klaren

gelösten Wald von Lager und Genist;

und da ergab sich, daß sie nicht aus List

und nicht aus Angst in sich so leise waren,

sondern aus Hören. Schrei, Geröhr

schien klein in ihren Herzen (Rilke 1982, 226).

Orpheus's song has also effected a transformation inside the animals: Orpheus has turned the animals' capacity for hearing from a small and undignified space into a large and sacred one - a temple:

[...] And where there had been

Just a makeshift hut to receive the music,

a shelter nailed up out of their darkest longing,

with an entryway that shuddered in the wind -

you built a temple deep inside their hearing (Rilke 1982, 227).

[...] Und wo eben

kaum eine Hütte war, dies zu empfangen,

ein Unterschlupf aus dunkelstem Verlangen

mit einem Zugang, dessen Pfosten beben, -

da schufst du ihnen Tempel im Gehör (Rilke 1982, 226). 
Without Orpheus' music, the animals would only have a "makeshift hut" for sheltering their "darkest longing". The song of Orpheus provides them with "a temple deep inside their hearing". It is as if the music of Orpheus brings acknowledgment of their "darkest longing”. It is possible to argue that the lines quoted above suggest that we should acknowledge desire instead of repressing it.

Marcuse has claimed that human beings instinctively rebel against repression and that this rebellion has found expression in innumerable works of art, such as Rilke's Sonnets to Orpheus (Marcuse 1998, 162). He has argued that art can be regarded as a manifestation of what Freud has termed "the return of the repressed" (Marcuse 1998, 140) and as an expression of "the Great Refusal" (Marcuse 1998, 160). The latter term refers to the refusal of toil and repression as symbolized by Prometheus. Marcuse has argued that Orpheus has liberated humankind and nature from toil and repression and that Narcissus has achieved harmony between the self and the world. According to Marcuse, Orpheus and Narcissus can be regarded as symbols of the end of alienation and of the possibility of reconciliation between human beings and objects of the natural world. When the rift between subject and object is abolished, they are free to be what they are (Marcuse 1998, 165).

\section{A New Sensibility}

The third sonnet of the first part of Sonnets to Orpheus explicitly addresses the question of being: “But when are we?” (“Wann aber sind wir?” Rilke 1982, 230 my translation) The sonnet answers this question by asking another question: "When does he bend/ the earth, the stars upon us?” (“Und wann wendet er/ an unser Sein die Erde und die Sterne?” Rilke 1982, 230 my translation) In Rilke's sonnet cycle, being is frequently associated with creating relationships between the human self and objects of the natural world. For example, in I, 15, a group of girls is encouraged to "[d]ance the orange" and to "create the relation" with it - both with its "pure, unyielding rind" and with its juice:

$$
\begin{aligned}
& \text { [...] } \\
& \text { girls, you warm, you silent girls coming, } \\
& \text { dance the taste of the fruit you test! }
\end{aligned}
$$

Dance the orange. [...]

\section{[...] Create the relation}

with the pure, the unyielding rind, with the juice that brims this happy thing! (Rilke 1964, 31).

\section{[...]}

Mädchen, ihr warmen, ihr stummen, tanzt den Geschmack der erfahrenen Frucht!

Tanzt die Orange. [...]

\section{[...] Schafft die Verwandtschaft}

mit der reinen, sich weigernden Schale, mit dem Saft, der die glückliche füllt!” (Rilke 1964, 30).

In II, 7, the reader is encouraged to create a relationship with flowers that have been picked by a group of girls. The sonnet addresses the flowers and describes their feelings. Thus the reader is encouraged to sympathize with the flowers. The flowers are not only personified but moreover likened to the girls who picked them: 
Flowers, finally to ordering hands related

(hands of girls of long ago and today),

who often across the garden table lay,

meekly wounded and wilted,

awaiting the water [...] (Rilke, 1964, 69).

Blumen, ihr schließlich den ordnenden Händen verwandte,

(Händen der Mädchen von einst und jetzt),

die auf dem Gartentisch oft von Kante zu Kante

lagen, ermattet und sanft verletzt,

wartend des Wassers [...] (Rilke 1964, 68).

Both I, 15 and II, 7 encourage the reader to create a relationship between themselves and a natural object and to sympathize with these natural objects. It has been pointed out that Rilke's poetic imagination possesses the "power of entering sympathetically into its subjects" (Young 1987, 9). It has further been pointed out that Sonnets to Orpheus attempts to overcome the "cleavage of conscious being into subject and object" (Webb 1975, 57). In the Eighth Duino Elegy, Rilke has pointed out that, unless we learn to create relationships between ourselves and the world, we will always be only spectators: "And we: spectators, always, everywhere,/ turned toward the world of objects, never outward." ("Und wir: Zuschauer, immer, überall,/ dem allen zugewandt und nie hinaus!" Rilke 1982, 194-195).

In Sonnets to Orpheus, Rilke has shifted his emphasis from seeing (his focus in New Poems) to hearing, tasting, touching and smelling - thus foregrounding the senses that have been neglected in an increasingly visual culture. Rilke has emphasized these senses and fused them into startling combinations, as the following lines from II, 5 illustrate:

Flower-muscle of the anemone

that little by little opens to the meadow-dawn,

until light's mighty polyphone pours down

into the womb from the sonorous sky, (Rilke 1964, 65).

Blumenmuskel, der der Anemone

Wiesenmorgen nach und nach erschlie $\beta$,

bis in ihren Schoo $\beta$ das polyphone

Licht der lauten Himmel sich ergießt, (Rilke 1964, 64).

The lines quoted above combine three different senses - seeing, hearing and touching. It has been suggested that Rilke deliberately sought to "transgress the boundaries of logic and categorisation that hold human beings captive within self-consciousness" (Komar 2010, 86). For example, the image of the anemone which opens itself to the world and receives "light's mighty polyphone" in II, 5 can be regarded as guiding readers toward what Marcuse has termed "a new sensibility".

Marcuse (1969, 4-5) has argued that humankind must develop a new sensibility - a sensibility which will not allow us any longer to accept and adjust ourselves to "the competitive performances required for well-being under domination, no longer capable of tolerating the aggressiveness, brutality, and ugliness of the established way of life". According to Marcuse $(1969,17)$, we must un-learn the habitual repression of desire in which we have been trained by civilization and learn to acknowledge our desire for fulfillment and happiness - we must develop "different instinctual needs, different reactions of the body as well as the mind". Marcuse $(1969,6)$ has called for " $a$ 
radical transvaluation of values. [...] a break with the familiar, the routine ways of seeing, hearing, feeling, understanding things so that the organism may become receptive to the potential forms of a nonaggressive, nonexploitative world".

The new sensibility envisioned by Marcuse is closely associated with receptivity and nonviolence. The anemone in II, 5 is described as receptive - "muscle of infinite receptivity" ("Muskel des unendlichen Empfangs" Rilke 1964, 65). The anemone is also (indirectly) described as non-violent:

We, the violent, though we endure

longer, when, in which of all our lives

are we finally open and receivers? (Rilke 1964, 64 my translation).

Wir Gewaltsamen währen länger.

Aber wann, in welchem aller Leben, sind wir endlich offen und Empfänger? (Rilke 1964, 64).

Significantly, in II, 5, receptivity is not identified with weakness but with "power/ and resolution of how many worlds!” ("Entschluß und Kraft von wieviel Welten!” Rilke 1964, 6465). These lines seem to imply that the anemone has acquired immense power and resolution in a long and ancient process of natural growth. In the sonnet cycle, nature is not only depicted as receiving but also as giving: "light's mighty polyphone pours down/ into the womb" of the anemone. In I, 12, nature is also described as giving - as generative and generous. According to this sonnet, a peasant who makes diligent plans and works hard for a good harvest nevertheless remains dependent on the generosity of nature:

\author{
However the peasant works and sows, \\ he never reaches those deep sources \\ where seeds turn into summer. Earth bestows. (Rilke 1964, 25). \\ Selbst wenn sich der Bauer sorgt und handelt, \\ wo die Saat in Sommer sich verwandelt, \\ reicht er niemals hin. Die Erde schenkt. (Rilke 1964, 24).
}

It should be emphasized that, with the exception of I, 1, all the sonnets discussed above feature women or contain images and values related to women (the earth, flower, fruit, womb; receptivity, non-violence, generosity). Critics have argued that Sonnets to Orpheus foregrounds an "aesthetics of femininity" (Ryan 1999, 16) and a "hermaphroditic poetics" (Kleinbart 1993, 142). Lou Andreas-Salomé, a former lover and life-long friend of Rilke's has remarked (in a book she wrote about the poet shortly after his death) that "all creativity is interaction between the feminine and masculine in ourselves” (1928, 40 "daß sich zum Zeugnis ihrer schöpferischen Kraft beide Geschlechtlichkeiten in eins vereinigen” my translation).

\title{
Narcissism Revisited
}

Lou Andreas-Salomé $(1928,61)$ has further remarked that Rilke's creative powers were derived from Eros, and that his poetry was not addressed to a single love object but to the entire universe. Similarly, David Young $(1987,7)$ has suggested that, unlike most sonnet cycles, Sonnets to Orpheus is not a love poem for "a particular person" but "a kind of extended love-poem to the world". This attitude can be noticed in II, 1, a sonnet which draws attention to the act of breathing. In this sonnet, breath is referred to as "[p]ure/ exchange unceasing between the great/ ether and our existence" ("Immerfort um das eigne/ Sein rein eingetauschter Weltraum" Rilke 1964, 56-57). These lines remind the reader that breathing is an act of exchange. In II,1, the 
narrator asks the air: "Do you know me, air, full of places where I/ used to be?" ("Erkennst du mich, Luft, du, voll noch/ einst meiniger Orte?" Rilke 1964, 56-57). The word "know" ("erkennen") indicates that this exchange is also a contact which engenders knowledge and recognition. In this sonnet, the narrator further describes breath as "[c]ounterweight/ in which I rhythmically occur" ("Gegengewicht,/ in dem ich mich rhythmisch ereigne” Rilke 1964, 56-57). These lines describe breathing as an erotic encounter between the speaker of the sonnet and the air. Robert Hass (1989, xli) has suggested that the sonnets "reflect how Rilke finally allowed the world to come flooding in on him after having held it off for such a long time". It is important to note that II, 1 describes breath also in terms of water (interestingly, Hass uses the word "flooding") - as "billow whose slow degrees/ of ocean take place/ in me" ("Welle, deren/ allmähliches Meer ich bin” Rilke 1964, 56-57). Freud's $(1961,15)$ "oceanic feeling” comes to mind.

It can be argued that the last tercet of II, 1 refers back to the second line of I, 1 because all these lines evoke the image of a tree, creating a link between trees and Orpheus, i. e. poetic expression: In II, 1, the air is referred to as "once smooth rind, roundness and leaf of my words" ("einmal glatte Rinde,/ Rundung und Blatt meiner Worte" Rilke 1964, 56-57). In I, 1, Orpheus is referred to as "tall tree in the ear" ("hoher Baum im Ohr" Rilke 1982, 226-227). The tree is a traditional symbol of rebirth and self-renewal; it is associated with Dionysus, who was worshipped in ancient Greece as the tree god (Bernstock 1991, 27). Like Orpheus, Dionysus is torn into pieces and transformed: "into air, water, earth, and fire" (Nietzsche 1999, 52). Dionysus is associated with music, intoxication, bliss, ecstasy and the fragmentation of the principium individuationis; his counterpart Apollo is associated with sculpture, light, harmony, self-knowledge, moderation and reason (Nietzsche 1999,14, 16-17, 27, 62). It has been claimed that "Rilke considered modern life under the domination of reason as an impoverished version of life that is unable to proffer deeper meaning to humankind" (Martinec 2010, 97). In the following letter, Rilke has given expression to his hope that his poems will counteract the narrow interpretation of life characteristic of rational modernity:

'More than once now I have suggested to you how in my life and in my work I am more and more driven only by the endeavour to correct wherever possible our old repressions which have taken from us our secrets and increasingly made them alien when in them we might live infinitely from fullness' (Rilke quoted in Martinec 2010, 97).

Marcuse has also claimed that our modern perception of life is very narrow. He has argued that erotic plenitude has been channeled into narrow genital sexuality (Marcuse 1991, 59). According to Marcuse, the entire human body is a source of erotic pleasure. What is more, he has argued that the universe is a source of erotic pleasure. Marcuse $(1998,48-49,169)$ has, in fact, envisioned an erotization of the universe or, to be more precise, the re-erotization of the universe. According to Marcuse, human beings were once capable of experiencing the world as suffused by Eros; they once felt at one with the universe. Marcuse has supported his claim by referring to the following remark by Freud in Civilization and Its Discontents:

'Originally the ego includes everything, later it detaches from itself the external world. The ego-feeling we are aware of now is thus only a shrunken vestige of a far more extensive feeling - a feeling which embraced the universe and expressed an inseparable connection of the ego with the external world' (Freud quoted in Marcuse 1998, 168, Marcuse's emphases). 
Based on the remark by Freud quoted above, Marcuse has argued that human beings, because they experienced unity between themselves and the world in the past, can experience it again. Freud has referred to the feeling of being at one with the universe as "oceanic feeling" (Marcuse 1998, 168). II, 1 with its images of air, water and earth that flow into each other is reminiscent of Freud's "oceanic feeling”.

Freud's remark on the "oceanic feeling" has served Marcuse as a starting point for his reinterpretation of Freud's concept of "primary narcissism". According to Marcuse $(1998,168)$, primary narcissism is akin to the "oceanic feeling": "Primary narcissism is more than autoeroticism; it engulfs the 'environment', integrating the narcissistic ego with the objective world”. As Judith Ryan $(1999,106)$ has pointed out, Lou Andreas-Salomé has also proposed a positive view of narcissism, arguing that "narcissistic and feminine impulses" help the individual to defy "the domination of reason over pleasure". It can be argued that Sonnets to Orpheus reflects a similar attitude: David Kleinbart $(1993,132)$ has suggested that, whereas Rilke tended to view narcissism as "sterile, solipsistic illness" during the first half of his literary career, he later came to view it as "a fertile, creative mode of existence". Like Erich Fromm, Marcuse has claimed that the dominant values of modern Western capitalist civilization are not biophilic but necrophilic - not life-enhancing but life-destroying. He has argued that we can only abolish "this deadly system of life" for once and all if we "learn to develop the new sensibility of life - of [our] own life and that of things" (Marcuse 1969, 40).

\section{Ecocriticism}

Both Marcuse and Rilke have criticized Western attitudes toward nature as life-destroying. Their work can be considered as anticipating crucial tenets of Ecocriticism. From the 1970s onwards, Ecocriticism has drawn attention to the fact that Western attitudes toward nature are destructive and misguided. According to Ecocritic William Rueckert (1996, 113), "man's tragic flaw is his anthropocentric (as opposed to biocentric) vision, and his compulsion to conquer, humanize, domesticate, violate, and exploit every natural thing." Rueckert $(1996,117)$ has argued that we will destroy the earth if we fail to accomplish "deep inner changes". It can be argued that both Marcuse's and Rilke's works are in tune with ecocritical ideas. In my opinion, both Marcuse and Rilke would agree with Rueckert's claim that we must develop "creative biospheric apperceptions, attitudes, and actions" (Rueckert 1996, 121) to prevent the destruction of our planet.

Marcuse (1969, 6-7) has argued that capitalism exploits and destroys human beings and the earth. He has claimed that capitalism produces misery and waste. A minority reaps huge profits, the masses live in poverty and oppression; meanwhile our planet is being destroyed. According to Marcuse (1969, x), we live under "the rules and regulations of a pseudo-democracy in a Free Orwellian World". Advances in science and technology have not been used to liberate humankind and the earth, but to enslave them (Marcuse 1998, 93).

Sonnets to Orpheus contains a forceful critique of the use of science and technology: Like Marcuse, Rilke has not rejected science and technology; he has criticized how they have been used (i.e. misused) so far. I, 18 depicts the domination of machines over humankind and the earth as harmful and irrational:

$$
\begin{aligned}
& \text { Master, you hear the New, } \\
& \text { trembling and droning? } \\
& \text { Come now heralds who } \\
& \text { praise it, intoning. }
\end{aligned}
$$

Really no hearing's still hale in this turmoil, 
[...]

See how it storms

in a rage to devour, enervates us, deforms (Rilke 1964, 37).

Hörst du das Neue, Herr, dröhnen und beben?

Kommen Verkündiger, die es erheben.

\author{
Zwar ist kein Hören heil \\ in dem Durchtobtsein, \\ [...] \\ Sieh, die Maschine: \\ wie sie sich wälzt und rächt \\ und uns entstellt und schwächt (Rilke 1964, 36).
}

The lines quoted above depict the effect of the domination of machines on human beings as crippling, weakening and numbing. The capacity of hearing, which plays such a vital role in the sonnet cycle, is impaired by the noise of machines.

In II, 10, machines are depicted as omnipresent and omnipotent - as tyrants who control our lives and own us body and soul: "Nowhere stands the machine aside, that we escape once,/ Where it oils and belongs to itself in the factory without noise." ("Nirgends bleibt sie zurück, da $\beta$ wir ihr ein Mal entrönnen/ und sie in stiller Fabrik ölend sich selbst gehört." Rilke 1964, 74-75). Like I, 18, this sonnet (II, 10) emphasizes the noise which is produced by machines. Besides, this sonnet argues that machines are a threat to everything that humankind has achieved. This threat persists as long as we allow machines to dominate our lives: "All we have won is threatened by the machine, so long/ as it, instead of obeying, as spirit dares to command." ("Alles Erworbne bedroht die Maschine, solange/ sie sich erdreistet, im Geist, statt im Gehorchen, zu sein." Rilke 1964, 74-75). II, 10 argues that we must make the machines obey and serve humankind, so that we can regain at least some measure of freedom and happiness. Whereas the two quartets of this sonnet criticize the domination of machines over humankind, its two tercets celebrate the magic and beauty of existence:

But still for us existence is enchanted: from a hundred places

it is still origin. A play of pure forces

that no one touches unless he kneels and admires.

The Unutterable, words fragilely slip by...

and from the most vibrant stones music anew aspires

building her deified house in the useless space of the sky (Rilke 1964, 75).

Aber noch ist uns das Dasein verzaubert; an hundert

Stellen ist es noch Ursprung. Ein Spielen von reinen

Kräften, die keiner berührt, der nicht kniet und bewundert.

Worte gehen noch zart am Unsäglichen aus...

Und die Musik, immer neu, aus den bebendsten Steinen, baut im unbrauchbaren Raum ihr vergöttlichtes Haus (Rilke 1964, 74). 
The lines quoted above describe existence as "enchanted" and as a "play of pure forces/ that no one touches unless he kneels and admires". The words "enchanted" and "touch" suggest that we cannot grasp existence only through reason and our sense of sight. These lines appear to intimate that there are invisible forces which we can only get in touch with through art - for example, through music or poetry.

\section{The Role of Poetry in Society}

II, 10 evokes both the beauty of art (of music and poetry) and the beauty of nature. In a similar manner, I, 2 evokes the beauty of Orpheus's song and of nature through the following words: "harmonious joy of song and lyre", "springtime veils", "trees" and "meadow" ("einigen Glück von Sang und Leier", "Frühlingsschleier”, "Bäume”, "Wiese” Rilke 1964, 4 my translation). William Rueckert $(1996,108)$ has also placed poetry into the context of nature: He has argued that we should perceive a poem as "a living thing" and as a space in which energy is stored renewable energy. According to Rueckert (1996, 109-110), when we read a poem, the energy stored in the poem is released and flows into and through our minds: "Energy flows from the poet's language centers and creative imagination into the poem and thence, from the poem (which converts and stores this energy) into the reader". When we read and discuss a poem in a class room or lecture hall, the energy stored in the poem is released and flows into multiple readers. This situation creates a "true interactive field because the energy flow is not just a twoway flow from poem to person as it would be in reading; the flow is along many energy pathways from poem to person, from person to person" (Rueckert 1996, 110). Rueckert has argued that if we perceive a poem as alive, we are more open and receptive to its meaning(s). In fact, he has claimed that rather than trying to extract coherent meaning(s) from a poem, we should try to be open to what a poem does:

The concept of a poem as stored energy (as alive, active, and generative, rather than as inert, as a kind of corpse upon which one performs an autopsy, or as an art object one takes possession of, or as an antagonist - a knot of meanings - one must overcome) frees one from a variety of critical tyrannies, most notably, perhaps, that of pure hermeneutics, the transformation of this stored creative energy directly into a set of coherent meanings. What a poem is saying is probably always less important than what it is doing (Rueckert 1996, 110).

Can a poem really do something? Both Marcuse and Rilke have given answers in the affirmative throughout their works. In I, 26, Orpheus, the archetypal poet, is described as being attacked, killed and torn to pieces by a group of rejected women. However, he is not really dead, but only transformed - into a spirit that suffuses the entire natural world: "in cliffs and lions lingered/ your music, in birds and trees. You still sing there." ("dein Klang noch in Löwen und Felsen verweilte/ und in den Bäumen und Vögeln. Dort singst du noch jetzt.” Rilke 1964, 52-53) Besides, Orpheus transforms his surroundings: "all the sharp/ stones they cast at you grew soft when nearing/ your heart and, touching you, were endowed with hearing." "“alle die scharfen/ Steine, die sie nach deinem Herzen warfen,/ wurden zu Sanftem an dir und begabt mit Gehör." Rilke 1964, 52-53) The last line of this sonnet even suggests that Orpheus' death was a necessary prerequisite for the emergence of human poets: "Only since hatred at last parceled you/ among us, are we hearers and a mouth for nature." ("Nur weil dich reißend zuletzt die Feindschaft verteilte,/ sind wir die Hörenden jetzt und ein Mund der Natur.” Rilke 1964, 52-53) These lines are reminiscent of the death and resurrection (or transformation) of Jesus Christ. In fact, during the medieval period, Orpheus became associated with Jesus Christ (Bernstock 1991, xxii). 
Like Rilke, Marcuse (1969, 40) has argued that art possesses transformative power: "Art alters experience by reconstructing the objects of experience - reconstructing them in word, tone, image". Marcuse $(1991,62)$ has further argued that literature draws attention to the fact that human perception has become increasingly limited and distorted: "[F]iction subverts everyday experience and shows it to be mutilated and false". Similarly, Rilke considered human perception in the modern world as narrow and deficient. Critics have argued that Duino Elegies and Sonnets to Orpheus aim to "stimulate the readers' imagination and free their minds from the constraints of modern thinking - thus tuning them into the Orphic melody of life" (Martinec 2010, 109). It has further been suggested that Rilke's sonnet cycle offers the reader a new orientation to the world that emphasizes “acknowledgment and responsiveness" (Eldridge 2014, 165). For example, II, 1 depicts breathing as an act of being responsive to the air. It further acknowledges breathing as our primary connection to the world:

\author{
How many parts of this space already were \\ within me! There's many a wind \\ like a son to me. \\ Do you know me, air, full of places where I used to be? (Rilke 1964, 57). \\ Wie viele von diesen Stellen der Räume waren schon \\ innen in mir. Manche Winde \\ sind wie mein Sohn.
}

Erkennst du mich, Luft, du, voll noch einst meiniger Orte?

(Rilke 1964, 56).

It should be noted that the wind has a special importance in Rilke's life and work. As Robert Hass (1982, xii) has pointed out, "Rilke seems to have needed, desperately, the feeling of freedom which he found only in open, windy spaces - Duino, Muzot." In Duino, Rilke conceived the plan to write Duino Elegies; in Muzot, he finished them ten years later, while, at the same time, he wrote Sonnets to Orpheus in February 1922 (MacIntyre 1964, viii). In Rilke's sonnet cycle, wind is associated with poetry. For example, in I, 3, poetry is referred to as "a different breath, about/ nothing. A gust inside the god. A wind." ("ein andrer Hauch./ Ein Hauch um nichts. Ein Wehn im Gott. Ein Wind." Rilke 1982, 230-231) According to these lines, poetry is something invisible about something invisible. In a similar vein, Marcuse $(1991,67)$ has argued that literature is saying-what-is-not. He has drawn attention to the works of the French writer Paul Valéry who has emphasized the significance of negation and absence:

\begin{abstract}
Paul Valéry insists on the inescapable commitment of the poetic language to the negation. The verses of this language 'ne parlent jamais que de choses absentes.' They speak of that which, though absent, haunts the established universe of discourse and behavior as its most tabooed possibility - neither heaven nor hell, neither good nor evil but simply 'le bonheur'. Thus the poetic language speaks of that which is of this world, which is visible, tangible, audible in man and nature - and of that which is not seen, not touched, not heard (Marcuse 1991, 67).
\end{abstract}

It should be noted that the works of Paul Valéry had a profound influence on Rilke's imagination and thought (Ryan 1999, 207).

According to Marcuse, avant-garde artists sought to disrupt and transcend habitual ways of perceiving the world. He has argued that art creates a vision of "an environment in which the 
nonaggressive, erotic, receptive faculties of man, in harmony with the consciousness of freedom, strive for the pacification of man and nature" (Marcuse 1969, 31). Marcuse (1969, 39) has further argued that we must learn "not to see things anymore in the medium of that law and order which has formed them", so that we can recognize possibilities for a different world. According to him, poetry is cognitive: It "performs the great task of thought: le travail qui fait vivre en nous ce qui n'existe pas (the effort which makes live in us that which does not exist)" (Marcuse 1991, 67-68). Poetry (as thought) can conjure up what does not exist. This idea is also expressed in one of Rilke's sonnets: II, 4 describes the coming into existence of an imaginary animal - a unicorn:

Oh, this is the animal that never was.

[...]

Really it was not. Of their love they made it, [...]

They did not feed him any corn, only the possibility he might exist, which gave the beast such strength (Rilke 1964, 63).

O dieses ist das Tier, das es nicht gibt.

[...]

Zwar war es nicht. Doch weil sie's liebten, ward ein reines Tier

[...]

Sie nährten es mit keinem Korn, nur immer mit der Möglichkeit, es sei (Rilke 1964, 62).

The unicorn becomes real because people believe in it and love it. In the last two lines of the sonnet, the unicorn is associated with a virgin (and thus with Jesus Christ) and a silver mirror (an allusion to Narcissus): "Unto a virgin he appeared.../ and was in the silver-mirror and in her" ("Zu einer Jungfrau kam es weiß herbei -/ und war im Silber-Spiegel und in ihr." Rilke 1964, 62-63).

Marcuse (1998, p. 160) has pointed out that the Surrealists believed that phantasy should be accorded the status of reality and that symbols and metaphors should be read literally. In the following quotation Marcuse assumes the voice of an imaginary Surrealist poet who addresses an imaginary "one-dimensional" reader, siding, of course, with the surrealist poet against the "one-dimensional” reader:

Understanding of my poetry presupposes the collapse and invalidation of precisely that universe of discourse and behavior into which you want to translate it. [...] then it will appear that my symbols, metaphors, etc. are not symbols, metaphors, etc. but mean exactly what they say. Your tolerance is deceptive. In reserving for me a special niche of meaning and significance, you grant me exemption from sanity and reason, but in my view, the madhouse is somewhere else (Marcuse 1991, 192).

In conclusion, this article has tried to show that there are many parallels between the ideas expressed in Rilke's Sonnets to Orpheus and Marcuse's works, such as Eros and Civilization, One-Dimensional Man and An Essay on Liberation. Both Marcuse and Rilke have depicted 
Orpheus as embodying and promoting values associated with the pleasure prinicple, such as the gratification of desire and the abolition of repression. In both writers' works, Orpheus is presented as the archetypal poet and musician who has liberated and reconciled humankind and nature. Both Marcuse and Rilke have foregrounded a new sensibility which is centered around receptivity and non-violence. Both writers have redefined narcissism in a positive manner - as the ability to feel at one with the universe and as a creative and fulfilling mode of being. Both writers have criticized traditional Western attitudes toward nature as destructive and misguided. Their works can be considered as anticipating crucial tenets of Ecocriticism. Both Marcuse and Rilke have argued that poetry possesses cognitive and transformative power. Both seek to encourage readers to transcend the narrow limits of rational thinking and discourses. It can be argued that the works of Marcuse and Rilke seek to inspire readers to be receptive and open to language that refuses to be imprisoned in the confines of what is considered rational by an ideology which seeks to justify and perpetuate an irrational and destructive system. 


\section{REFERENCES}

Andreas-Salomé L. (1928). Rainer Maria Rilke. Leipzig 1928.

Bernstock J. E. (1991). Under the Spell of Orpheus: The Persistence of a Myth in Twentieth-Century Art. Illinois 1991.

Eldridge H. V. (2014). “Figuring Finitude: Rilke's Sonnets to Orpheus”. H. V. Eldridge, Lyric Orientations: Hölderlin, Rilke, and the Poetics of Community (2014) 156-192. Ithaca.

Freud S. (1961). Civilization and Its Discontents. Translated and edited by J. Strachey. New York 1961.

Hass R. (1989). "Introduction". Translated and edited by S. Mitchell, The Selected Poetry of Rainer Maria Rilke (1989) xi-xliv. New York.

Kleinbart D. (1993). "Woman Within: Developments Leading to The Sonnets to Orpheus and the Completion of the Duino Elegies". D. Kleinbart. The Beginning of Terror: A Psychological Study of Rainer Maria Rilke's Life and Work (1993) 128-149. New York.

Komar K. L. (2010). “The Duino Elegies”. Eds. K. Leeder \& R. Vilain, The Cambridge Companion to Rilke (2010) 80-94. Cambridge.

Marcuse H. (1969). An Essay On Liberation. Boston 1969.

Marcuse H. (1998). Eros and Civilization: A Philosophical Inquiry Into Freud. London 1998.

Marcuse H. (1991). One-Dimensional Man: Studies in the Ideology of Advanced Industrial Society. Boston 1991.

Martinec T. (2010). “The Sonnets to Orpheus”. Eds. K. Leeder \& R. Vilain, The Cambridge Companion to Rilke (2010) 95-110. Cambridge.

Nietzsche F. (2000). The Birth of Tragedy and Other Writings. Cambridge 2000.

Rilke R. M. (1964). Sonnets to Orpheus. Translated by C. F. MacIntyre. Berkeley 1964.

Rilke R. M. (1982). The Selected Poetry of Rainer Maria Rilke. Edited and translated by S. Mitchell. New York 1982.

Rueckert W. (1996). "Literature and Ecology: An Experiment in Ecocriticism”. Eds. C. Glotfelty \& H. Fromm, The Ecocriticism Reader: Landmarks in Literary Ecology (1996) 105-123. Georgia.

Ryan J. (1999). Rilke, Modernism and Poetic Tradition. Cambridge 1999.

Webb E. (1975). "The One and the Many: The Ambiguous Challenge of Being in the Poetry of Yeats and Rilke”. E. Webb, The Dark Dove: The Sacred and Secular in Modern Literature (1975) 54-67. Seattle.

Young D. (1987). “Introduction”. R. M. Rilke, Sonnets to Orpheus (1987). Translated by D. Young, 7-11. Connecticut. 